\title{
Selenium - An Important Antioxidant in Crops Biofortification
}

\author{
P. Ježek, P. Škarpa, T. Lošák, J. Hlušek, M. Jůzl and P. Elzner
}

Additional information is available at the end of the chapter

http://dx.doi.org/10.5772/50356

\section{Introduction}

\subsection{Selenium in human body}

For human body selenium is essential element playing important role in body antioxidation system; it is considered individual antioxidant that can cooperate with other antioxidants, such as $\mathrm{C}$ and $\mathrm{E}$ vitamins and in processes protecting the cells from free radicals. In such manner selenium protects a body from development of cancer, cardiovascular diseases and masculine sterility [1]. Selenium participates in thyroid hormone metabolism, immune system, inhibits virulence, slows down the development of AIDS through reducing the speed of HIV development. Furthermore, it can reduce the risk of spontaneous abortions as well [2]. Balanced content of selenium in human food helps in the case of complications connected with diabetes and affects also the prevention of asthma. Through free radicals inhibition selenium moderates harmful effects of radiation [3]. Selenium is important for proper function of cerebral neurotransmitters and reduces epileptic waves at children. Selenium deficiency is connected with acceleration of senility and development of Alzheimer's disease. Selenium affects in a positive manner human mind and mental wellness [4].

\subsection{Sources and forms of selenium in human nutrition}

Basic source of selenium in human nutrition is food, which can contain various amounts and chemical forms of selenium, depending on its type and origin. Food, as well as biological systems, can contain inorganic (selenite - $\mathrm{SeO}_{3}{ }^{2-}$, selenate - $\mathrm{SeO}_{4}{ }^{2-}$ ) and organic forms of selenium (Se-amino acids, methylated forms, Se-proteins) [5]. Dominant form of selenium in a food affects acceptability of selenium for body and its availability in proteosynthesis and production of methylated selenium compounds [6]. In comparison with inorganic forms of 
selenium, the organic ones are more available for a man, as they can be absorbed more easily; they are metabolised into structures of Se-proteins and other non-specific proteins and are excreted by renal system in less extent [7]. For example, Se-met, located in plant products, enters directly to metabolism of proteins, replacing essential Met or being part of metabolism of selenium [8]. On the other hand, inorganic selenium is absorbed in mineral form and deposited in tissues in small extent. Finally, considerable part of inorganic selenium is eliminated in urine. In comparison with nutrition using $\mathrm{SeO}_{3^{2-}}$, if organic selenium is used for nutrition, selenium content in urine is lower [3]. During simulated experiment the same forms of selenium were detected in gastric liquids, intestinal liquids and in fresh garlic plants (Allium sativum L.) [9], chive plants (Allium schoenoprasum L.) [10] and vegetable treated with $\mathrm{SeO}_{3}{ }^{2-}$, containing Se-methylselenocysteine as main Secompound. These results indicate that the mentioned plants can be good source of Secompounds for body [9].

Absorption of organic sources of selenium from food is $70-95 \%$ depending on present forms [8]. Generally, a body can well use selenium from Se-met, Se-cys and from most of plant food. Availability of selenium from animal products is intermediate and in some cases even low [8]. Meat and fish are rich source of selenium, mostly in Se-cys form. On the other hand, vegetable and fruit are lower-grade source of selenium, occurring mostly in more acceptable form - Se-met [11]. Surai [3] presents the following acceptability of Se forms: Semet $>\mathrm{SeO}_{4} 4^{2-}>\mathrm{SeO}_{3}{ }^{2-}$. Content of selenium in meat and animal products is listed in table 1.

\begin{tabular}{|c|c|c|c|c|c|}
\hline \multirow{2}{*}{ Food } & \multicolumn{5}{|c|}{ Content of Se mg.kg-1 $^{-1}$} \\
\cline { 2 - 6 } & USA & Canada & Finland* & Germany & $\begin{array}{c}\text { Czech and } \\
\text { Slovakia }\end{array}$ \\
\hline Pork & $0.04-0.24$ & 0.31 & $0.01-0.09$ & 0.19 & $0.02-0.07$ \\
\hline Beef & $0.06-0.27$ & - & $0.01-0.03$ & - & 0.02 \\
\hline Chicken & $0.10-0.12$ & - & $0.08-0.14$ & - & $0.07-0.11$ \\
\hline Pork liver & 0.64 & 0.36 & $0.34-0.51$ & 0.17 & $0.09-0.34$ \\
\hline Beef liver & 0.43 & 0.50 & $0.03-0.13$ & 0.09 & $0.02-0.14$ \\
\hline Pig kidneys & $1.90-2.21$ & 3.22 & $1.54-1.76$ & 0.78 & $0.97-1.84$ \\
\hline Beef kidneys & $1.45-1.70$ & 2.31 & $0.62-0.78$ & 0.95 & $0.2-1.02$ \\
\hline Freshwather fish & $0.34-0.37$ & 0.59 & $0.12-0.53$ & 0.38 & $0.05-0.38$ \\
\hline Sea fish & $0.12-1.41$ & $0.75-1.48$ & $0.11-0.80$ & - & - \\
\hline Milk & 0.06 & 0.15 & $0.001-0.004$ & 0.20 & 0.003 \\
\hline Curd & - & 0.07 & $0.02-0.03$ & - & - \\
\hline Cheese & 0.09 & - & $0.01-0.06$ & - & $0.02-0.04$ \\
\hline Youghurt & 0.05 & - & 0.003 & - & $0.004-0.008$ \\
\hline Eggs & 0.10 & 0.39 & $0.02-0.16$ & - & $0.18-0.24$ \\
\hline
\end{tabular}

*data before Se biofortification

Table 1. Content of selenium in meat and animal products in various countries of the world [12] 


\subsection{Function and metabolism of selenium in human body}

Metabolism of selenium depends on chemical forms of selenium in food and various forms of selenium carry out various functions, based on their specific metabolism [13]. Methylated Se-compounds can be important in cancer prevention and are not available for proteosynthesis. Se-methylselenocysteine and derivates of $\gamma$-glutamile, which can be found in plants of Allium and Brassica genus, have anticarcinogenic effect. As for retention through tissues and activity of glutathion-peroxidase (GSH-Px = protein with antioxidation effects), selenium from fortified plants of Allium and Brassica genus is as available for body as selenium from inorganic sources $\left(\mathrm{SeO}_{4}{ }^{2-}, \mathrm{SeO}_{3}{ }^{2-}\right)$; anyway, in comparison with anorganic sources of selenium it is more effective in reduction of cancer presence. Se-amino acids, as well as Se-met are transformed to structures of proteins [14, 15]. In Se-proteins selenium is incorporated in form of synthesized Se-cys [16], which is $21^{\text {st }}$ biogenic amino acid [17]. The most important and known Se-proteins in human body include glutathion-peroxidase (GSH-Px), which creates functionally most important group of Se-proteins participating in protection of cells from oxidation caused by free radicals. Activity of GSH-Px in a body is considered to be an indicator of selenium supply [18]. Next Se-protein is enzyme thioredoxin reductase (TR), regulating redox processes in a cell. Se-protein P creates $60 \%$ of total selenium in plasma, where it can participate in selenium transport and carries out the function of antioxidant. Another important group of Se-proteins is iodothironin deiodinase, which participates in metabolism in thyroid gland hormone - thyroxine. Selenium is also the part of proteins, which maintain the integrity of sperm flagellums and W Se-protein, being necessary for muscle metabolism $[5,16]$.

This knowledge indicates that bioavailability and effectiveness of selenium in a body is evaluated according to selenium form in the food or in food supplement and function of such Se-compound in a body. At present there is no universal method for evaluation of selenium availability from food and it is recommended to use combination of various methods [3]. To understand effect of selenium coming from common food and in particular from a food fortified with selenium to human health in full extent, the multidisciplinary attitude of a team consisting of research workers in the fields of medical, chemical, food and agricultural sciences will be necessary [13].

\subsection{Recommended intake of selenium, its deficiency and toxicity}

Recommended daily intake of selenium for adult men and women is $55 \mu \mathrm{g}$ per day. Recommended intakes for other age categories and for pregnant and lactating women are listed in table 2. In many countries of Europe, Asia and part of Africa the intake of selenium from food doesn't reach recommended daily intake [13]; the deficiency of selenium in Europe is commonly known [19]. Daily intakes of selenium in other parts of the world are listed in table 3.

Low intake of selenium endangers mostly the people with reduced intake of food (seniors) and people with higher need of this essential element, including pregnant and lactating women, growing and developing children, sportsmen and hardworking people [4]. 


\begin{tabular}{|c|c|c|}
\hline Life stage & Age & $\boldsymbol{\mu g ~ S e . d a y}^{\mathbf{1}}$ \\
\hline \multirow{2}{*}{ Infants } & $0-6$ months & 15 \\
\cline { 2 - 3 } & $7-12$ months & 20 \\
\hline \multirow{3}{*}{ Children } & $1-3$ years & 20 \\
\cline { 2 - 3 } & $4-8$ years & 30 \\
\cline { 2 - 3 } & $9-13$ years & 40 \\
\hline Adults & $14<$ years & 55 \\
\hline Pregnants & -- & 60 \\
\hline Lactation & -- & 70 \\
\hline
\end{tabular}

Table 2. Recommended daily intake of selenium by individual age categories [20]

\begin{tabular}{|c|c|c|c|}
\hline Country & $\begin{array}{c}\text { Intake of Se } \\
\left(\boldsymbol{\mu g} \text { Se.day }{ }^{-1}\right)\end{array}$ & Country & $\begin{array}{c}\text { Intake of Se } \\
\left(\boldsymbol{\mu g} \text { Se.day } \mathbf{~}^{\mathbf{1}}\right.\end{array}$ \\
\hline Australia & $57-87$ & New Guinea & 20 \\
\hline Belgium & $28-61$ & New Zealand & $55-80$ \\
\hline Brazil & $28-37$ & Poland & $30-40$ ** \\
\hline Czech Repubic & $10-25^{*}$ & Portugal & 37 \\
\hline China & $7-4990$ & Austria & 48 \\
\hline Denmark & $38-47$ & Saudia Arabia & 15 \\
\hline Egypt & 29 & Slovak Republic & 38 \\
\hline France & $29-43$ & Slovenia & 30 \\
\hline Croatia & 27 & Serbia & 30 \\
\hline India & $27-48$ & Spain & $31-38$ \\
\hline Ireland & 50 & Sweden & 70 \\
\hline Italy & 43 & Switzerland & $30-36$ \\
\hline Japan & $104-199$ & Turkey & 106 \\
\hline Canada & $98-224$ & USA & $29-39$ \\
\hline Germany & 35 & UK & $200-350$ \\
\hline Nepal & 23 & Venezuela & - \\
\hline Netherlands & $39-54$ & - & \\
\hline
\end{tabular}

*based on concentration of Se in urine of adults; ${ }^{* *}$ calculated

Table 3. Daily intake of selenium from food in various states of the world [6]

Deficiency of selenium in human nutrition affects biological functions being in relationship with function of Se-proteins and metabolism of selenium. The risk of occurrence of degenerative diseases (in particular cancer, cirrhosis, cardiovascular diseases, diabetes, etc.) 
increases [21]. In China, in areas with critical deficiency of selenium two killer diseases are epidemiologically spread: "Keshan disease", characterized with failures of myocardium function - the so-called "cardiomyopathy" and "Kashin-Beck disease" - the osteoartropathy, that means a disease characterized with damage of cartilages causing the deformation of bone structures [19, 3].

As for intake of selenium in the frame of improvement of nutritive value of food, it is important to know its safe upper limit of daily intake separating positive and potential negative effects on human body. Maximum safe daily intake of selenium for men and women (pregnant, as well as lactating) older than 14 years is $400 \mu \mathrm{g}$ per day. Maximum safe daily intake of selenium for particular age categories is presented in table 4 . Chronically over limit daily intake of selenium can have negative and (depending on doses) even toxic effects. In case of chronic intake the toxic effects of organic and inorganic forms are similar. At immediate overdose the symptoms of toxicity are more intensive at inorganic forms of selenium [20].

\begin{tabular}{|c|c|c|}
\hline Life stage & Age & $\boldsymbol{\mu g}$ Se.day \\
\hline \multirow{2}{*}{ Infants } & $0-6$ months & 45 \\
\cline { 2 - 3 } & $7-12$ months & 60 \\
\hline \multirow{3}{*}{ Children } & $1-3$ years & 90 \\
\cline { 2 - 3 } & $4-8$ years & 150 \\
\cline { 2 - 3 } & $9-13$ years & 280 \\
\hline Adults* & $>14$ years & 400 \\
\hline
\end{tabular}

*including pregnants and lactation

Table 4. Maximum safe daily intake of selenium for particular age categories [20]

Selenosis as result of over limit intake of selenium from food at human body was described for the first time in 60-ties in China (province Hubei). The richest mediator of toxic doses of selenium was cereals [22]. The most common symptoms of selenosis are fragility and loss of hair and nails, diarrhea, hives, nausea, exhaustion garlic odour on the breath, decreased level of haemoglobin, mottled teeth, abnormalities of nervous system [3]. Figure 1 demonstrates the damage of nails at people living in north-western India, where the food sources are naturally rich in selenium. Content of selenium in hair and nails of intoxicated people was 8-9 times higher in comparison with healthy people [22].

In United States, in states South Dakota and Wyoming, with naturally high content of selenium in soil, no symptoms of overdose with selenium were observed at local inhabitants with daily intakes of selenium higher than $724 \mu \mathrm{g}$ per day. During an experiment performed also in United States selenium has been administered to cancer patients in doses 1,600 and 3,200 $\mu \mathrm{g}$ per day. Monitored persons showed only moderate symptoms of toxic influence of selenium. In China the symptoms of selenosis were described at sensitive people with daily intake of selenium higher than $910 \mu \mathrm{g}$ per day. This knowledge shows that toxic doses of selenium are more than 10 times higher than physiological need of a body [3]. 


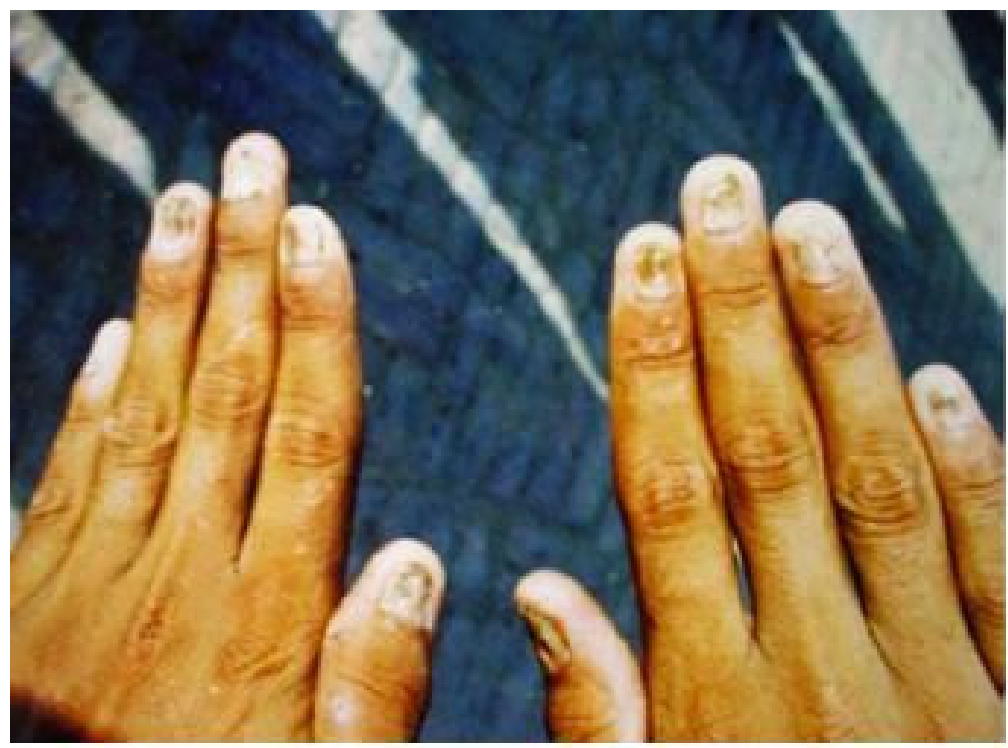

Figure 1. Deformation of nails at people intoxicated with selenium in north-western part of India [22]

\section{Selenium in soil}

Basic source of selenium in nutrition of man and animals is soil. Problems resulting from low content of selenium in human nutrition led to mapping selenium content in soils [23]. Content of selenium in soils is evaluated based on relationship to human physiological needs and physiological needs of livestock and based on average content of selenium in soils of particular monitored regions. Gupta, Gupta [24] consider that deficient total content of selenium in soil is lower than $0.6 \mathrm{mg} \cdot \mathrm{kg}^{-1}$. Feed produced on soils with content of selenium lower that mentioned value causes deficiency of selenium at animals. According to Oldfield [25], the content of selenium lower than $0.5 \mathrm{mg} \cdot \mathrm{kg}^{-1}$ of soil in relation to nutrition of animals is limiting and the content lower than $0.3 \mathrm{mg} \mathrm{Se}^{-\mathrm{kg}^{-1}}$ is already very deficient. In China the criterion for evaluation of content of selenium in soil was occurrence of endemic diseases caused by deficiency of selenium - "Keshan disease" and "Kashin-Beck disease". Both these diseases occur in China, in areas with total content of selenium in arable land lower than $0.125 \mathrm{mg} . \mathrm{kg}^{-1}$ of soil. Limiting content of selenium in a soil, over which these diseases don't occur is 0.123 to $0.175 \mathrm{mg} \cdot \mathrm{kg}^{-1}$ and the content of selenium in soil higher than $3 \mathrm{mg} \cdot \mathrm{kg}^{-1}$ is excessive. On the contrary, in areas with contents of selenium in soil higher than $3 \mathrm{mg} \cdot \mathrm{kg}^{-1}$ the symptoms connected with over limit content of selenium, the so-called selenosis occur [26].

Content of selenium in soils and biological material varies in wide extent. Kabata-Pendias and Pendias [27] present average content of selenium in soils of the world $0.33 \mathrm{mg} . \mathrm{kg}^{-1}$ and average contents of selenium vary depending on soil type and locality from $0.25 \mathrm{mg} \cdot \mathrm{kg}^{-1} \mathrm{in}$ bleached sands (podsol) to 0.37 mg. $\mathrm{kg}^{-1}$ in histosols. 
Content of selenium in soil is affected with structure and intensity of parent material (native rock) erosion and its structure [24], as well as with atmosphere, being the source of selenium air pollutants of natural and anthropogenic origin. Natural source of emissions are selenium volatilization in form of dimethyl-selenide $\left(\left(\mathrm{CH}_{3}\right)_{2} \mathrm{Se}\right)$ from the soil, plants, fresh and sea water and volcanic activity [28]. Anthropogenic source of selenium is combustion of coal and metallurgic facilities. Another anthropogenic source of selenium includes mineral fertilizers enriched with selenium, being used in areas with low reserves of available selenium in soil. For example, in Finland now the mineral fertilizers are enriched with

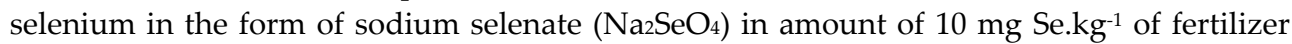
[29]. Availability of selenium applied in such manner is usually 5 to $30 \%$. Residual part is retained in soil, leached, eventually released to atmosphere through volatilization [30].

The climate affects the contents of selenium in soil, too. Current researches in China showed that the soils developing in humid and moderately humid tropical and subtropical conditions contain higher amount of selenium soluble in water $\left(>0.3 \mathrm{mg} \cdot \mathrm{kg}^{-1}\right.$ of soil), soils developing in steppe and desert conditions contain medium amount of selenium soluble in water $\left(0.14-0.3 \mathrm{mg} \cdot \mathrm{kg}^{-1}\right.$ of soil) and, finally, the soils developing in humid and moderately humid conditions of mild climate contain altogether small amount of selenium [26].

Selenium in soil exists in several inorganic forms: as elementary selenium $\left(\mathrm{Se}^{0}\right)$, selenide $\left(\mathrm{Se}^{2}\right)$, selenite $\left(\mathrm{SeO}_{3}{ }^{2-}\right)$, selenate $\left(\mathrm{SeO}_{4}{ }^{2-}\right)$ and in organic forms, for example as Se-met. In cultivated soils $\mathrm{SeO}_{3}{ }^{2-}$ and $\mathrm{SeO}_{4}{ }^{2-}$ dominate. Dominating form of selenium in a soil, its mobility and availability for plants are affected with soil reaction, aeration, hydrological regime and soil redox potential [31,3]. Based on development of these factors, individual forms of selenium in a soil undergo transformations regulated with oxidation-reduction processes. Dependence of selenium form on $\mathrm{pH}$ and redox potential is demonstrated in figure 2. Oxidation-reduction relations among individual selenium forms are demonstrated in figure 3.

Selenates are highly soluble in water and don't create stable complexes that means, they represent the form of selenium that can be easily leached and is available for plants. This form of selenium dominates in aerated soils with neutral and higher $\mathrm{pH}$. In soils with high content of $\mathrm{Ca}$ and $\mathrm{Mg} \mathrm{CaSeO}_{4}$ and $\mathrm{MgSeO}_{4}$ are created; these compounds represent total selenium soluble in a soil [27]. In soils rich in organic matter and water and without air entry selenates are transformed and reduced to less mobile forms [32]. With decreasing $\mathrm{pH}$ and redox potential in soil $\mathrm{SeO}_{3}{ }^{2-}$ dominate, being less available for plants than $\mathrm{SeO}_{4}{ }^{2-}$ [30]. This fact results from different physical characteristics of soils containing $\mathrm{SeO}_{3}{ }^{2-}$ or $\mathrm{SeO}_{4}{ }^{2-}$ and from different mechanism of absorption of both anions. Selenite- is firmly bound with a positive charge [30,27] and in acid soils creates stable complexes with iron hydroxides. With next development of soil acidity and reducing conditions selenium in soil occurs in form of selenides $\left(\mathrm{Se}^{2-}\right)$, which form $\mathrm{KHSe}, \mathrm{NH}_{4} \mathrm{HSe}$ and MnSe and also, similarly to $\mathrm{SeO}_{3}{ }^{2-}$, create stable complexes with iron hydroxides [27]. Selenides in a soil can form the chains of diselenides (RSeSeR) volatilizing from a soil. This mechanism ensures the release of selenium from a soil to the atmosphere [33]. In highly reducing conditions selenium can be present in a soil in its elementary form being available only for some bacteria [34]. 


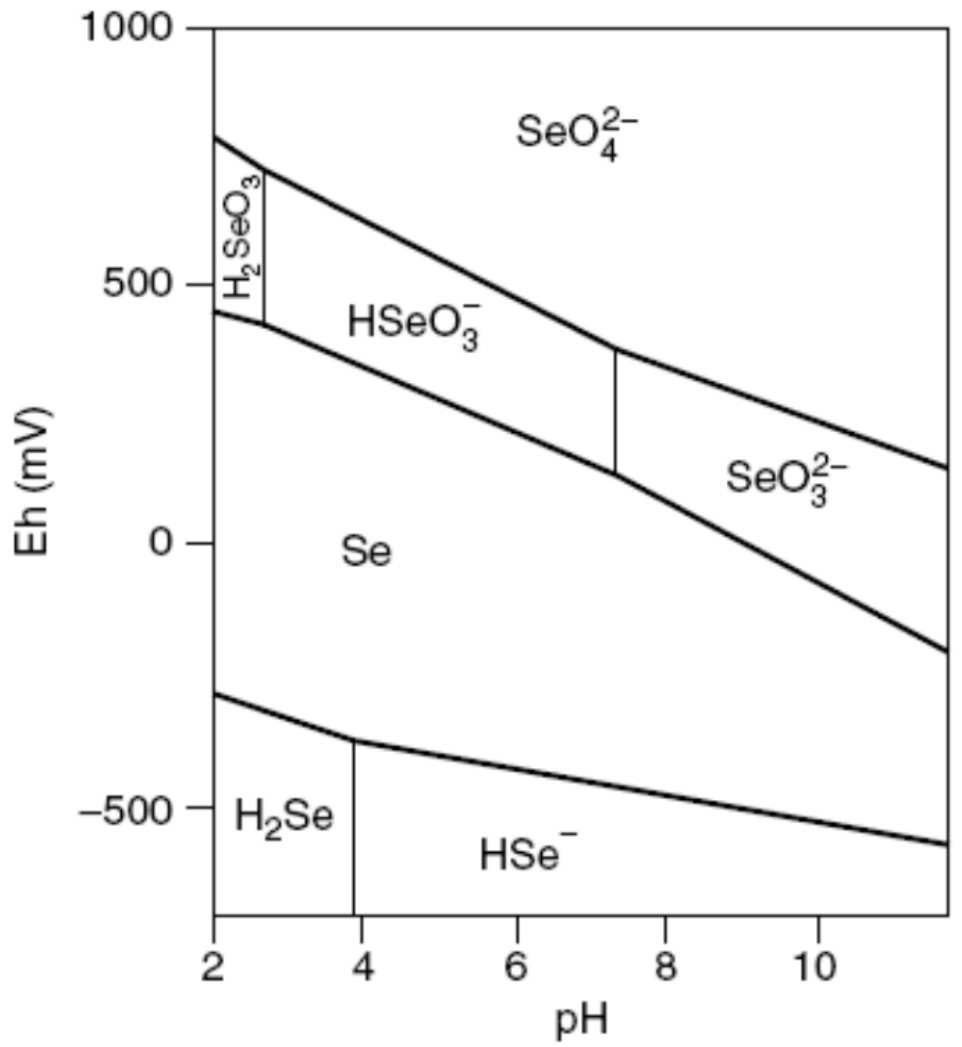

Figure 2. Distribution of selenium in a soil depending on $\mathrm{pH}$ and redox potential [31]

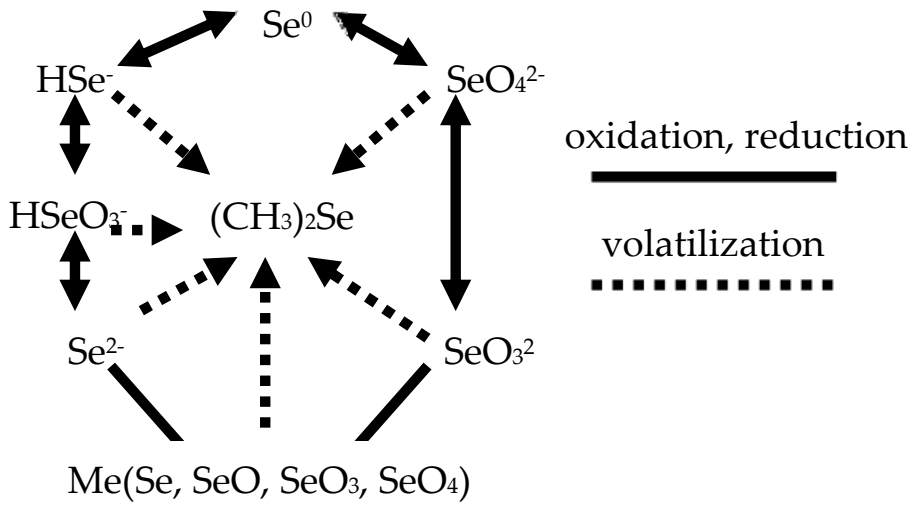

Figure 3. Diagram demonstrating the transformation of selenium in a soil [27] 


\section{Selenium in plants}

Uptake of selenium by plants and its total amount in plant tissues are influenced with many factors, including the content of selenium in a soil, its form, soil reaction, soil redox potential, mineral structure of soils, mineral fertilizers and rain precipitation. Another factor participating in total uptake of selenium is the atmosphere. Selenium cycle in an agroecosystem is demonstrated in the figure 4 . Selenium is not considered essential element for plants.

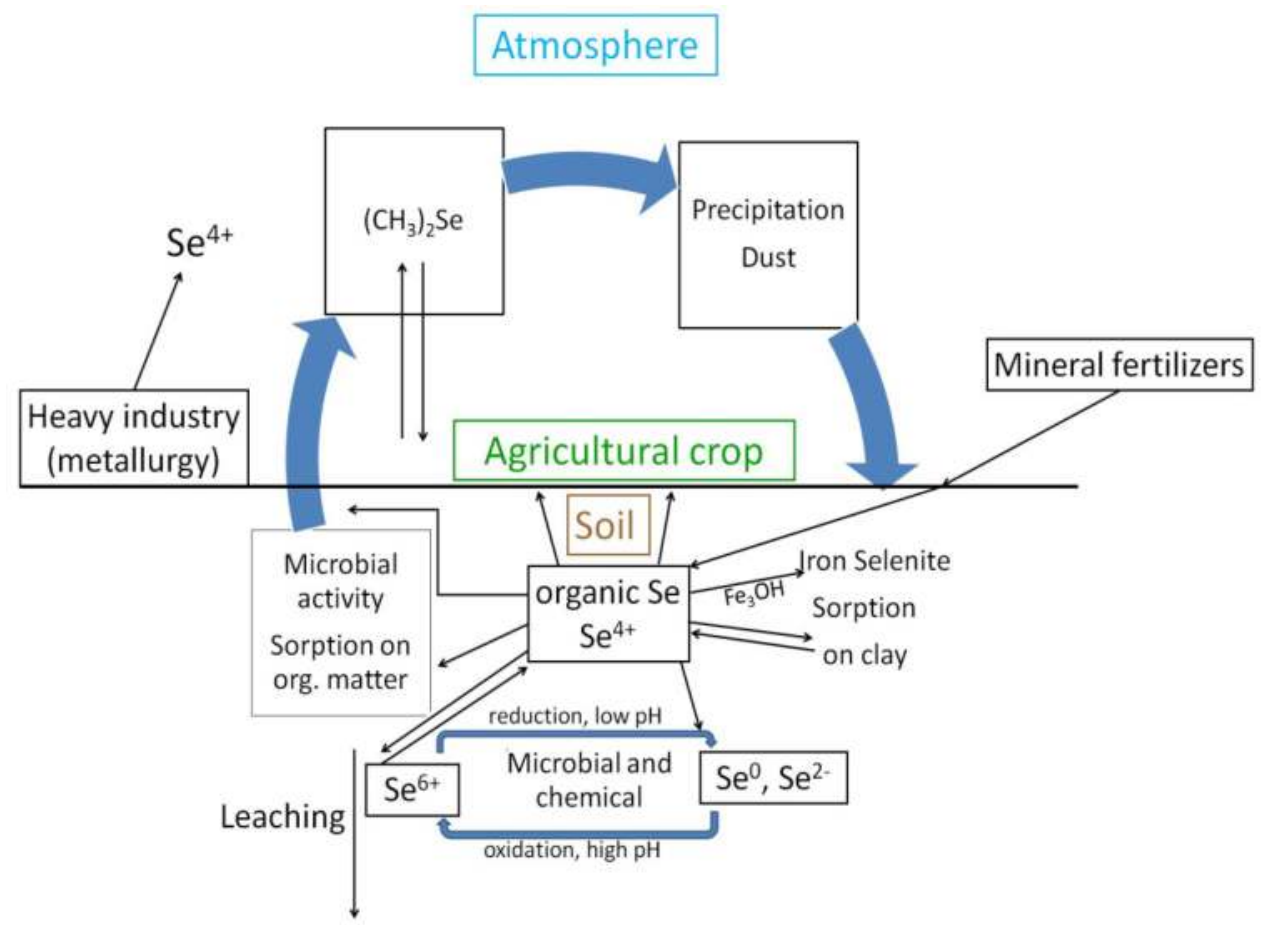

Figure 4. Selenium cycle in an agroecosystem [35]

In terms of availability, the form of selenium is more important factor than the total amount of selenium in a soil [3]. Selenium can be absorbed by a plant in inorganic form as a selenate $\left(\mathrm{SeO}_{4}{ }^{2-}\right)$ or selenite $\left(\mathrm{SeO}_{3}{ }^{2-}\right)$ or in organic form as Se-amino acid, for example as Semethionine (Se-met) [31]. According to description by various authors, $\mathrm{SeO}_{4}{ }^{2-}$ is well soluble and for plants easily available form of selenium. Results of the experiment performed by Zayed et al. [36] showed that the plants contained the highest amount of selenium after treatment with $\mathrm{SeO}_{4}{ }^{2-}$, furthermore Se-met a $\mathrm{SeO}_{3}{ }^{2-}$. Cauliflower (Brassica oleracea var. botrytis L.) and cabbage (Brassica oleracea convar. capitata L) contained 10 times higher amount of selenium after treatment with $4.5 \mathrm{mg} \mathrm{SeO} 4^{2-} \cdot \mathrm{kg}^{-1}$ of soil in comparison with variants treated with $4.5 \mathrm{mg} \mathrm{SeO} 3^{2-} \cdot \mathrm{kg}^{-1}$ of soil [37]. Other forms of selenium Se - selenides ( $\left.\mathrm{Se}^{2-}\right)$ and elementary selenium $\left(\mathrm{Se}^{0}\right)$ are usually located in reduction condition of an environment and are not available for the plants [3]. 
In soil the ions are relatively fast transported to roots surface through mass flow, resulting from water uptake by plant and subsequent transpiration. Next ion transport mechanism in a soil is diffusion. Ions can entry to roots passively or actively [38]. Plant roots receive selenate and organic selenium actively against electrochemical gradient. Sulfate $\left(\mathrm{SO}_{4}{ }^{2-}\right)$ ion transmitter participates in $\mathrm{SeO}_{4}{ }^{2-}$ uptake. Process of $\mathrm{SeO}_{4}{ }^{2-}$ uptake is positively regulated by $\mathrm{O}$-acetylserin and negatively by $\mathrm{SO}_{4}{ }^{2-}$ and glutathione [39].

$\mathrm{SeO}_{3}{ }^{2-}$ uptake mechanism still remains unclear. Some authors suppose that one possibility of $\mathrm{SeO}_{3}{ }^{2-}$ uptake is passive diffusion [40, 41, 39, 36]. Asher et al. [42] presents that after application of $\mathrm{SeO}_{4}{ }^{2-}$ to tomato roots the concentration of $\mathrm{SeO}_{4}{ }^{2-}$ in xyleme exudates was 6 13 times higher than in surrounding solution, while after application of $\mathrm{SeO}_{3}{ }^{2-}$ the concentration of $\mathrm{SeO}_{3}{ }^{2-}$ in xyleme exudates was lower than in surrounding solution. On the contrary, $\mathrm{Li}$ et al. [43] present that the uptake of $\mathrm{SeO}^{2-}$ in wheat is active process, probably partly mediated by $\mathrm{PO}_{4}^{3-}$ transmitter.

Johnsson [44] states that the most important factors participating in variable amount of selenium received by a plant are organic matter, content of selenium in a soil and soil reaction. Selenium uptake is in positive correlation with increasing soil $\mathrm{pH}$, but the influence of $\mathrm{pH}$ decreases with increasing content of clay minerals and organic matter. In alkaline $\mathrm{pH}$ and with development of oxidation conditions in a soil the prevailing form of selenium in a soil is $\mathrm{SeO}_{4}{ }^{2-}$, which is more available for plants. Haygarth et al. [45] state that at $\mathrm{pH} 6.0$ the pasture vegetation received $47 \%$ of total received amount of ${ }^{75} \mathrm{Se}$ from soil and after the increasing of $\mathrm{pH}$ value to 7.0 the uptake of ${ }^{75} \mathrm{Se}$ from the soil increased to $70 \%$. Selenium form in a soil and thus its availability by a plant relates also to soil redox potential. Soil samples maintained in soils saturated with water showed significant reduction of redox potential and available selenium [46].

Other important factors participating in uptake of selenium are competitive relationships among ions at soil absorption, condensation reactions in a soil and interaction of ions during the uptake by a plant. Goh and Lim [47] describe the influence of $\mathrm{PO}_{4}^{3-}$ an $\mathrm{SO}_{4} 4^{2-}$ ions to absorption of selenium in tropical soils. They state that $\mathrm{PO}_{4}{ }^{3-}$ influenced the absorption of $\mathrm{SeO}_{3}{ }^{2-}$ and $\mathrm{SeO}_{4}{ }^{2-}$ more markedly in comparison with $\mathrm{SO}_{4}{ }^{2-}$. Stronger competition of $\mathrm{PO}_{4}{ }^{3-}$ towards $\mathrm{SeO}_{3}{ }^{2-}$ and $\mathrm{SeO}_{4}{ }^{2-}$ can be ascribed to higher charge $\mathrm{PO}_{4}{ }^{3-}$. This fact suggests that selenium in a soil becomes more active after application of $\mathrm{H}_{2} \mathrm{PO}_{4}^{-}$, which inhibits the absorption of $\mathrm{SeO}_{3}{ }^{2-}$. Nakamaru et al. [48] state that high content of available phosphorus or its low absorption increase the availability of selenium for plants. Application of $160 \mathrm{~kg}$ of phosphorus per ha in form of $\mathrm{H}_{3} \mathrm{PO}_{4}$ or concentrated superphosphate to alfalfa (Medicago sativa L.) increased the concentration of selenium [31].

Competitive relationship of selenium is described in connection with uptake of sulphur; the intensity of interaction of selenium and sulphur depends on forms of competing ions. Cartes et al. [49] state that after application of $\mathrm{SO}_{4}{ }^{2-}$ the content of selenium in grass shoot decreased by $33 \%$. Increase of concentration of $\mathrm{SO}_{4}{ }^{2-}$ from 0.25 to $10 \mathrm{mM}$ decreased the uptake of $\mathrm{SeO}_{3}{ }^{2-}$ by broccoli plants (Brassica oleracea var. italica Plenc) by $33 \%$ [36]. Increased content of 
$\mathrm{SO}_{4}{ }^{2-}$ inhibited most of all the uptake and volatilization of $\mathrm{SeO}_{4}{ }^{2-}$ in comparison with $\mathrm{SeO}_{3}{ }^{2-}$ and Se-met [36]. These mentioned interactions explain the decrease of availability of selenium after application of some mineral fertilizers.

Based on interactions in uptake of ions by a plant, increased content of selenium in plant tissues can decrease the content of $\mathrm{N}, \mathrm{P}$ and $\mathrm{S}$, as well as inhibit the absorption of some heavy metals, especially $\mathrm{Mn}, \mathrm{Zn}, \mathrm{Cu}, \mathrm{Fe}$ and $\mathrm{Cd}$. On the contrary, the application of $\mathrm{N}, \mathrm{P}$ and $\mathrm{S}$ can decrease the uptake of selenium through roots and this way ensure safe concentration of selenium to other nutrients in areas with toxic reserve of available selenium in a soil [27].

Besides the roots the plants are able to receive the ions also through aboveground plant organs from the solutions, which adhered on plant surface. Efficiency of uptake at foliar application of an ion depends on speed of ion absorption through aboveground plant organs and its mobility. Mechanism of selenium uptake by a plant and its metabolism is compared to mechanism of sulphur uptake and metabolism. This similarity could demonstrate the rate of selenium absorption at foliar application. Bukovac and Wittwer [50] describe the rate of absorption of ${ }^{35} \mathrm{~S}$ isotope in chemical form $\mathrm{SO}_{4}{ }^{2-}$ by primary leave of bean plant (Phaseolus vulgaris L.). Twenty four hours after application the leaves have absorbed $20 \%$, 48 hours after application they have absorbed $30 \%$, four days after application they have absorbed $50 \%$ and eight day after application they have absorbed $70 \%$ of applied substance. In comparison with other elements the absorption of sulphur has been medium fast and it has been mobile in plants. Thus, based on chemical similarity, similar mechanism of uptake and metabolism of selenium and sulphur, we can assume that absorption of selenium, the same as absorption of sulphur by plant is medium fast and it is mobile in a plant. Absorption rate and mobility of selenium after foliar application of $\mathrm{Na}_{2} \mathrm{SeO}_{4}$ in potato plants (Solanum tuberosum L.) are demonstrated in figure 5. Anyway, these values don't show the rate of absorption of selenium through assimilation organs but demonstrate the rate of accumulation of selenium in tubers since the time of foliar application.

Humid environment in the vicinity of applied salt determines the rate of ions penetration through hydrophilic epicuticular layer. In order to improve physical-chemical characteristics of agrochemical substances, detergents are used. Gissel-Nielsen [35] states that after addition of a detergent into applied selenium solution the concentration of selenium in treated plants doubled in comparison with its concentration in plant treated without wetting agent.

Important factor at foliar application is the concentration of applied solution. At foliar application the selenium ions diffuse from the surface of leaves to epidermal cells. There is strong correlation between solution concentration on the leaf surface and ions absorption rate, anyway, too high concentration can damage the leaf surface [51]. Absorption rate is limited with damage of ectodesmata [52]. Concentration of solution at foliar application of selenium should be chosen with care, based on recommendations concerning the nutrition with microelements. 


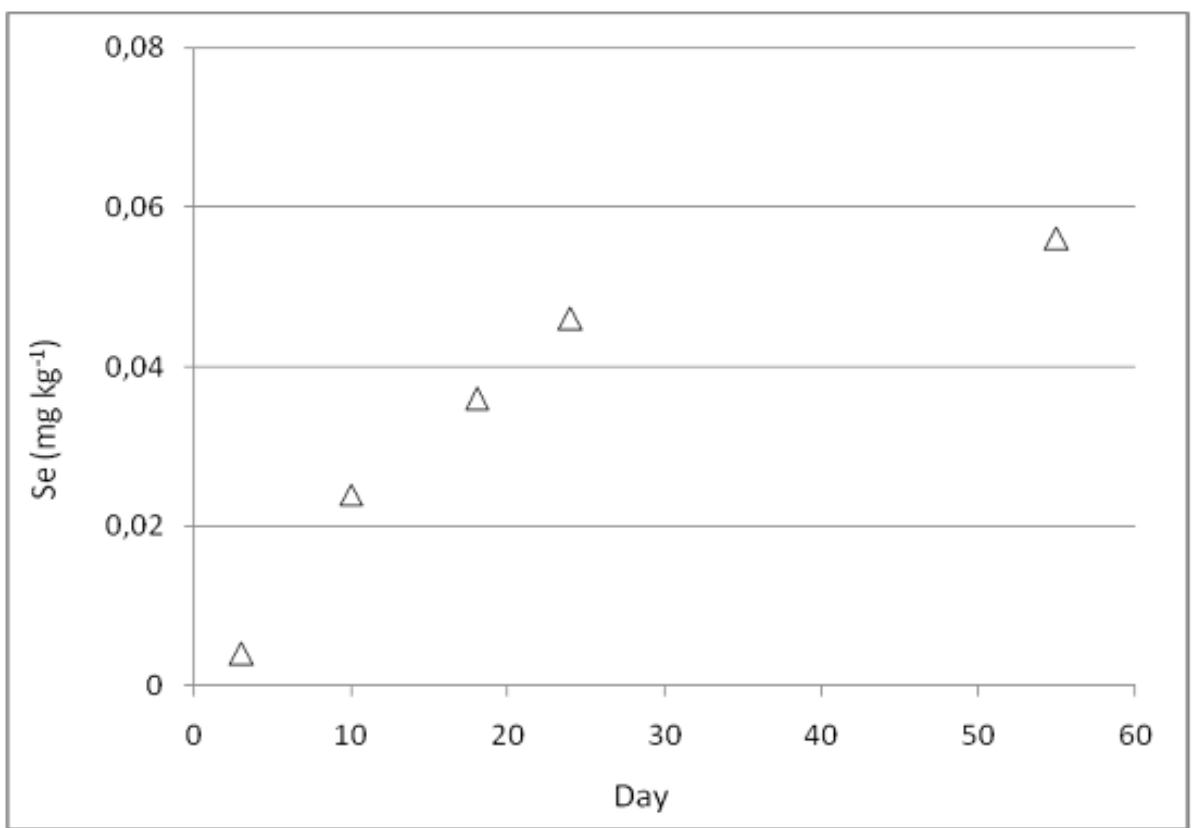

Figure 5. Increase of concentration of selenium in potato tubers after foliar application [11]

Selenium is not considered essential nutrient of vascular plants although in case of its deficiency the reduction of rice (Oriza sativa L.) and wheat (Triticum eastivum L.) growth, higher sensibility of Perennial Ryegrass (Lolium perenneL.) and lettuce (Lactuca sativa L.) to UV radiation [8] were observed. Xue et al. [53] state that low doses of selenium Se (0.1 mg. $\mathrm{kg}^{-1}$ of soil) stimulated in experiment performed in a container the growth of lettuce (Lactuca sativa L.) planting. Pedrero et al. [54] describe protective effect of selenium from harmful effects of $\mathrm{Cd}$ in broccoli plants (Brassica oleracea var. italica Plenc). It is not clear yet, to which extent selenium affects physiologic processes of plants through its participation in metabolism and to which extent the plant metabolism is affected with interactions among selenium and other elements at their uptake by a plant.

Physiological function of selenium in plants is not fully-known and the physiological reactions of various plants to selenium vary very much. Some plant species grow at soils contaminated with selenium, they are tolerant to selenium and accumulate its high amounts. Anyway, most of plants are sensitive to high contents of selenium [39]. Rani et al. [55] state toxic concentration of selenium in plant tissues, resulting in statistically demonstrative crop reduction. For brown mustard (Brassica juncea L.) it represents $104.8 \mathrm{mg}$

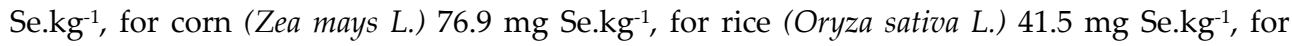
wheat (Triticum eastivum L.) $18.9 \mathrm{mg}$ Se. $\mathrm{kg}^{-1}$. Visual symptoms of toxic influence of selenium have been described for plants of wheat (Triticum eastivum L.), which have been grown on soils contaminated with selenium in the area Punjab in India. The symptoms include snow white chlorosis with rose colour on lower side of leaves and on leaf sheath [56]. 
Selenium can be considered useful element for plants, which bound large amounts of selenium [31]. The plants have been divided into three groups based on their ability to accumulate selenium:

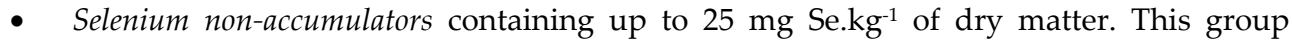
include most of crops, such as cereals, potatoes, grass, fruit, vegetable and many weed species growing on common soils; content of selenium is not increased [31]. Typical extent of selenium concentration in their tissues is $0.01-1.0 \mathrm{mg} \cdot \mathrm{kg}^{-1}$ of dry matter. There are differences among plant species growing on the same locality concerning the amount of received selenium [3].

- Secondary selenium accumulators - plants growing on soils with low and medium reserve

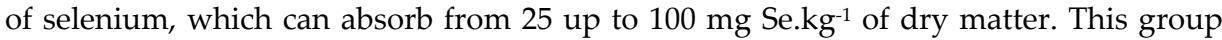
includes many various species, as well as Aster, Astragalus, Atriplex, Brassica, Castilleja, Comandra, Grindelija, Machaeranthera and others [31,3]. Concentrations of selenium in these plants generally exceed $1 \mathrm{mg} \cdot \mathrm{kg}^{-1}$ of dry matter and plants of this group are tolerant to salinization of soils [39].

- Selenium accumulators - can contain 100 - 10000 mg Se.kg-1 of dry matter. This group includes the species Astragalus, Machaeranthera, Haplopappus and Stanleya. These species grow on soils contaminated with selenium - with content of selenium higher than 5 mg.kg-1 of soil [24] and are responsible for selenoses of grazing animals. Selenium accumulators can contain hundred times more selenium than selenium nonaccumulators growing on the same soil [31].

Transformation and assimilation of selenium in plants is in close relation with sulphur metabolism. Most of enzymes participating in reduction of $\mathrm{SO}_{4}{ }^{2-}$ are involved in reduction of $\mathrm{SeO}_{4}{ }^{2-}$. Exception can be the last level of selenium reduction where $\mathrm{SeO}_{3}{ }^{2-}$ is reduced to $\mathrm{Se}^{2-}$. This stage runs non-enzymatically, while the reduction of $\mathrm{SO}_{3}{ }^{2-}$ to $\mathrm{S}^{2-}$ is catalyzed by sulphite reductase [40]. Transformation of $\mathrm{SeO}_{4}{ }^{2-}$ into organic compounds runs in plant leaves. Arvy [41] described that within 3 hours $50 \%$ of $\mathrm{SeO}_{4}{ }^{2-}$ was transported from roots to aboveground parts of bean (Phaseolus vulgaris L.) plants, while in the case of $\mathrm{SeO}_{3}{ }^{2-}$ most of selenium remains in roots. Selenate received by a plant is at first reduced to $\mathrm{SeO}_{3}{ }^{2-}$. This reaction is catalyzed with ATP-sulfurylase enzyme; this reaction produces reduction intermediary phosphoselenate (APSe). Formed $\mathrm{SeO}_{3}{ }^{2-}$ is reduced to selenotrisulphide (GSSeSG) using glutathione (GSH). Selenotrisulphide is at first reduced to selenoglutathione (GSSeH), creating $\mathrm{Se}^{2-}$ in the next step. During the reduction of GSSeSG and GSSeH reducing coenzyme NADPH is consumed. Selenide reacts with O-acetylserine (O-AS) and produces Se-cysteine (Se-cys). Cascade of $\mathrm{SeO}_{4}{ }^{2-}$ reduction continues up to formation of Se-cys in chloroplasts. Se-cys serves as precursor of synthesis of Se-met, which can be transformed to structure of other Se-compounds through subsequent metabolic processes [31, 40, 22, 57, 39]. Se-compounds identified in plants are listed in table 5.

$\mathrm{SeO}^{2-}$ is assimilated in a similar manner, too. Selenite is reduced to other forms of selenium in roots. Reduction of $\mathrm{SeO}_{3}{ }^{2-}$ can run directly or enzymatically and final product $\mathrm{Se}^{2-}$ reacts with O-acethylserine, forming Se-cys. If Se-cys is in higher concentrations accumulated in 
roots, an inhibition of selenium metabolism can occur. Selenite can be transformed to other forms of selenium also in non-enzymatic way, thus the accumulation of Se-cys in roots needn't lead to selenium metabolism blocking [60]. Diagram of reduction of $\mathrm{SeO}_{4}{ }^{2-}$ and $\mathrm{SeO}^{2-}$, is demonstrated in figure 6.

\begin{tabular}{|l|l|}
\hline Selenate & $\gamma$-glutamyl-Se-methylselenocysteine \\
\hline Selenite & Se-proponylselenocysteine selenooxide \\
\hline Se-cysteine & Se-methylselenomethionine \\
\hline Se-methionine & Selenocystathionine \\
\hline Selenocystine & Dimethyl diselenide \\
\hline Selenohomocysteine & Selenosinigrin \\
\hline Se-methylselenocysteine & Selenopeptide \\
\hline$\gamma$-glutamil-selenocystathionine & Selenocysteineselenic acid \\
\hline Selenomethionine selenooxide & Selenowax \\
\hline Dimethylselenide & Se-propylselenocysteine \\
\hline$\gamma$-glutamyl-Se-methionine & \\
\hline
\end{tabular}

Table 5. Se-compounds identified in plants $[58,59]$

Toxic effect of selenium in plants is attributed to interactions with sulphur metabolism. Replacement of sulphur cysteine (Cys) and methionine (Met) amino acids with selenium amino acids Se-met and Se-cys can disturb the biochemical reactions and enzymatic functions inside the cells [22].

Important knowledge is that in case of selenium accumulators selenium is not the part of protein structure. For selenium accumulators almost $80 \%$ of total selenium is within the structure of Se-methylselenocysteine. Other non-protein amino acids identified in selenium accumulators include selenocystathionine, Se-methylselenomethionine, $\gamma$-glutamyl-Semethylselenocysteine, $\gamma$-glutamyl- selenocystathionine and selenohomocysteine [58]. On the contrary, in the case of selenium non-accumulator most of selenium is part of proteins; this facts indicates that selenium accumulators have developed detoxication mechanism, in which selenium is removed from proteosynthesis [3]. Tolerance to selenium can be induced through its deposition to vacuoles in the form of $\mathrm{SeO}_{4}{ }^{2-}$ and in the case of selenium accumulators through deposition of non-protein seleno-amino acids [39]. Another possible protection of plants from toxic influence of selenium is its volatilization in the form of dimethyl-selenide [57, 3]. Dimethyl-selenide is the main volatilizing form of selenium in the case of selenium non-accumulators [40]. Next volatilizing Se-compound is dimethyldiselenide, which was detected in selenium hyperaccumulator Astragalus racemosus L. [61]. Amount of volatilized selenium varies and depends on plant species. Determination of volatilization intensity is complicated with microbial volatilizations of selenium in soil and plant rhizosphere [39]. 

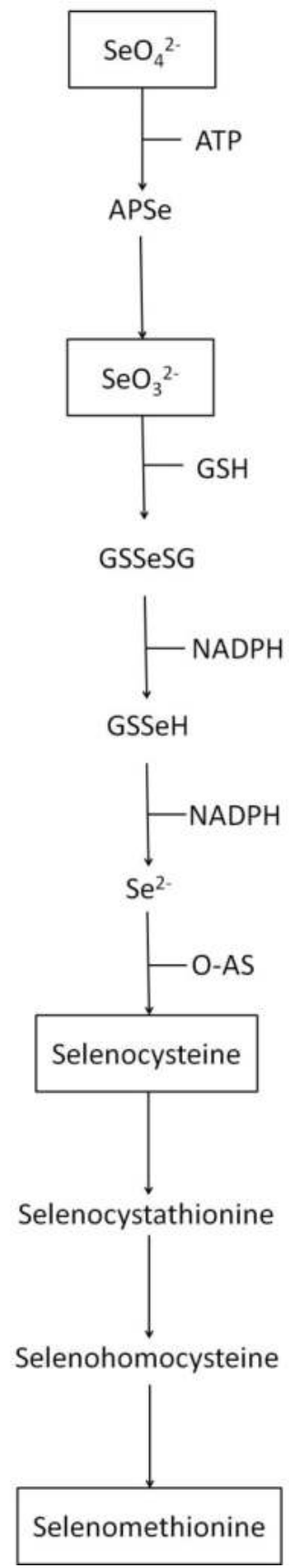

Figure 6. Diagram of reduction of selenium and percentage distribution of various forms of selenium in a plant [31] 
Selenium affects amino acids metabolism. Ježek et al. [62] describe the influence of foliar application of selenium to spectrum of amino acids in potato tubers. The experiment was performed to examine the effect of foliar application of selenium as sodium selenite (200 or $400 \mathrm{~g} \mathrm{Se} / \mathrm{ha}$ ) at the tuberisation stage on a spectrum of amino acids in tubers of two varieties. The trends of the amino acids were consistent in both years of the study. Application of Se increased the relative content of total essential (EAA) and non-essential (NEAA) amino acids relative to the controls (Variety 1: EAA 16.81-21.73\% and NEAA 14.18-18.63\%; Variety 2: EAA $4.71-13.00 \%$ and NEAA $5.78-6.49 \%$ ). The increase in the content of phenylalanine (Phe) was particularly significant (up to $48.9 \%$ ) when also the contents of aspartic acid (Asp), glutamic acid (Glu), threonine (Thr) and tyrosine (Tyr) increased significantly compared with the controls depending on variety (figure 7).
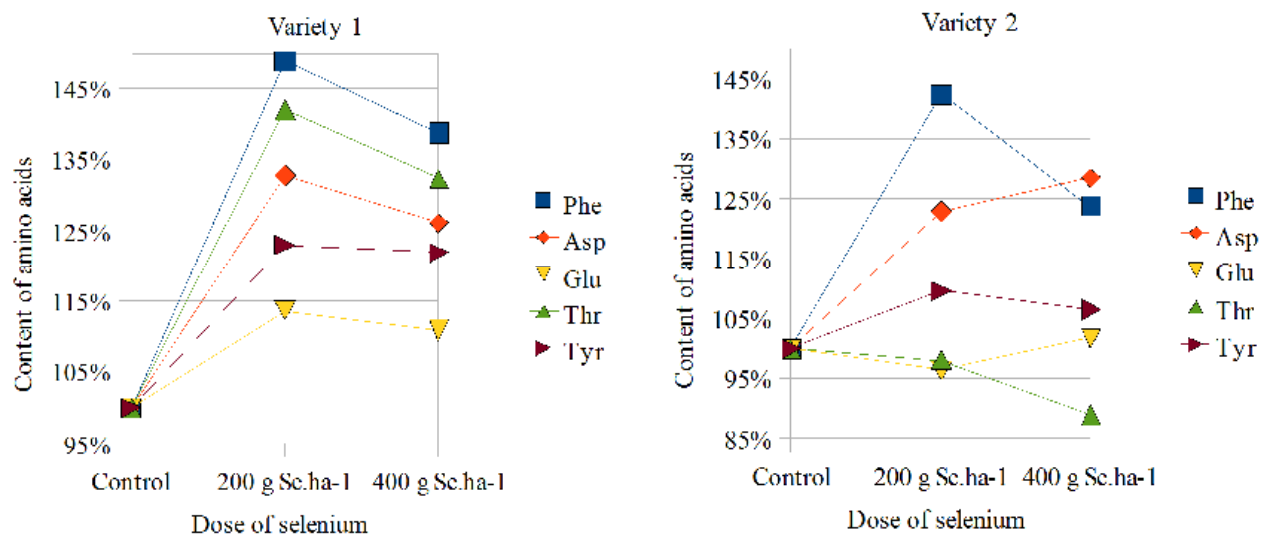

Figure 7. Reaction of amino-acid metabolism after selenium treatmen

\section{Fortification of crops with selenium}

Fortification of crops with selenium can be one of the ways enabling to increase the content of selenium in human and animal food chain. For example, in Finland extremely low content of selenium in food and animal feed caused health complications connected with deficiency of selenium in nutrition [29]. Average content of selenium in the soils in Finland is $0.2-0.3 \mathrm{mg} . \mathrm{kg}^{-1}$; climatic conditions, low $\mathrm{pH}$ and high contents of iron cause formation of stable selenium complexes. In consequence, only $5 \%$ of total content of selenium is soluble in soil and acceptable for plants [63]. By these reasons 1969 the decision was made that selenium will be used as additive of mineral mixtures for animals in doses of $0.1 \mathrm{mg}$ Se. $\mathrm{kg}^{-1}$ in the form of sodium selenite $\left(\mathrm{Na}_{2} \mathrm{SeO}_{3}\right)$. This measure influenced positively health of the animals but had no impact on human nutrition as the transport of inorganic form of selenium to animal products is insufficient [29]. Following intensive research was based on key role of plants in food chain. This research was focused on selection of selenium form and method of selenium application, taking into account soil conditions of Finland, crops 
species and their development stages in compliance with optimization of human nutritional needs and environment protection [64]. Based on research results sodium selenate $\left(\mathrm{Na}_{2} \mathrm{SeO}_{4}\right)$ was selected for fortification of crops suitable for conditions in Finland; since 1984 it has been added to NPK fertilizers during their production. Since 1998 current dose of selenium is $10 \mathrm{mg} \cdot \mathrm{kg}^{-1}$ of fertilizer [29].

After 1998 this measure has increased 15 times the content of selenium in spring cereals and varies between $0.13-0.18 \mathrm{mg} \cdot \mathrm{kg}^{-1}$ of dry matter. In winter cereals the content of selenium increased at average only $2-7$ times and varies between $0.02-0.07 \mathrm{mg} \cdot \mathrm{kg}^{-1}$ of dry matter. The difference between spring and winter cereals is determined through fertilization using NPK fertilizers. Fertilization before sowing of winter cereals uses much less these fertilizers and during the winter added $\mathrm{SeO}_{4}{ }^{2-}$ is reduced to less available $\mathrm{SeO}_{3}{ }^{2-}$ [65]. Average content of selenium in Finnish potatoes is $0.033 \mathrm{mg} \cdot \mathrm{kg}^{-1}$ of dry matter, that means it is three times higher than before fortification with selenium [66] and since 1998 the content of selenium in meet and meet products has increased 2-6 times in comparison with the period before such fortification. Content of selenium in beef varies between $0.28-0.48 \mathrm{mg} . \mathrm{kg}^{-1}$ of dry matter and in pork between $0.4-0.7 \mathrm{mg} \cdot \mathrm{kg}^{-1}$ of dry matter [65].

At present the intake of selenium in Finnish population is optimal. The most important source of selenium in nutrition of Finnish population are animal products (meat, milk, eggs), covering $70 \%$ of total intake of selenium $[29,64]$. Source of selenium for nutrition of animals and for production of animal products fortified with selenium Se includes plant feeds produced from plants fertilized with fertilizers fortified with selenium. These feeds contain organic selenium. Fortification with selenium in Finland is not aimed to particular crops but influences contents of selenium in all basic industry and also in food due its wide application in plant production.

Content of selenium in agricultural products can be multiplied with relatively small amounts of selenium. Important criterion in agronomic fortification with selenium is the amount of accumulated selenium in edible and further processed parts of plants. In experiment performed by Carvalho et al. [67], during which the tomatoes (Lycopersicon esculentum Mill.), lettuce (Lactuca sativa L.), radish (Raphanus sativus L.) and strawberry (Fragaria magna Thuill.) were fortified with selenium most of applied selenium (excepting the lettuce) accumulated in inedible parts of plants. Author states that mentioned species are suitable for fortification with selenium. Amount of selenium analysed in edible parts of plants varied in wide extent. The highest content of selenium in edible parts of plants was determined in lettuce. Method of selenium distribution in cereals is described by Koutník and Dočekalová [68], who describe the way of selenium distribution in Oat (Avena sativa L.) plants after application of $\mathrm{Na}_{2} \mathrm{SeO}_{3} .5 \mathrm{H}_{2} \mathrm{O}$. The highest content of selenium in full-grown plants was detected in grains, leaves and in chaff, respectively in descending order. In potato plants selenium after application accumulates in more extent in leaves, roots and stolons than in tubers. Concentration of selenium in tubers was in

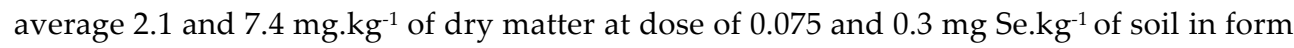
of $\mathrm{Na}_{2} \mathrm{SeO}_{4}$ [69]. Jůzl et al. [70] state that content of selenium after application of $\mathrm{Na}_{2} \mathrm{SeO}_{3}$ 
in aboveground parts of potatoes was higher by one third than its content in tubers. Škarpa and Richter [71] applied selenium foliary with dosage of $300 \mathrm{~g} \mathrm{Se}^{-h^{-1}}\left(\mathrm{Na}_{2} \mathrm{SeO}_{3}\right)$ in final stages of elongation growth and after blooming of Opium Poppy (Papaver somniferum). Such application reduced the yield - in average by $11.7 \%$. Content of selenium in poppy seeds increased from $139 \mu \mathrm{g} \cdot \mathrm{kg}^{-1}$ to $757 \mu \mathrm{g} \cdot \mathrm{kg}^{-1}$ of seed. Also the uptake of selenium by poppy vegetation was demonstrative and due to foliar application increased 4.8 times (figure 8).

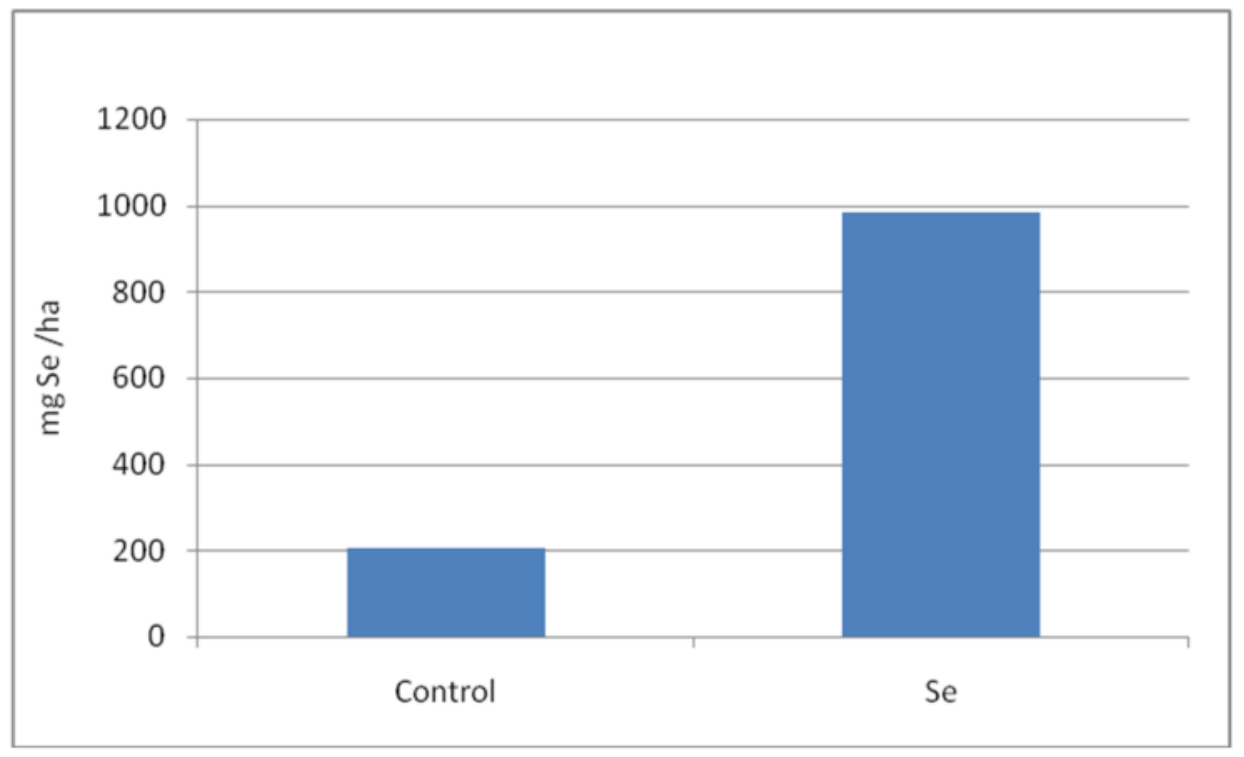

Figure 8. Selenium uptake by poppy seeds (mg per ha) [71]

Application of selenium to green poppy capsules after blooming increased the amount of selenium in poppy seeds even more significantly - see table 6.

\begin{tabular}{|l|l|l|l|l|l|}
\hline \multirow{2}{*}{} & \multicolumn{6}{|l|}{ Dose of Se $\left(\mathrm{g} \cdot \mathrm{ha}^{-1}\right)$} \\
\cline { 2 - 7 } & 0 & 25 & 50 & 100 & 200 \\
\hline Se content $\left(\mu \mathrm{g} \cdot \mathrm{kg}^{-1}\right.$ seeds) & 537 & 841 & 1,118 & 2,271 & 4,912 \\
\hline
\end{tabular}

Table 6. Content of selenium in poppy seeds at graduated doses during foliar application of selenium [71]

Selenium applied foliarly in form of $\mathrm{Na}_{2} \mathrm{SeO}_{3}$ in doses 50 and $150 \mathrm{~g}$ of selenium per ha at the beginning of elongation growth (stage R1 by Schneiter and Miller, [72]) of sunflower (Helianthus annuus). Similarly to poppy, the foliar application of selenium decreases the yields of achenes by 3.7 or $15.8 \%$. Contents of oil decreased moderately, too. Lower dose of selenium (50 g.ha-1) stimulated the content of oil acid in achenes. Increase of selenium content in sunflower is demonstrated in figure 9. 


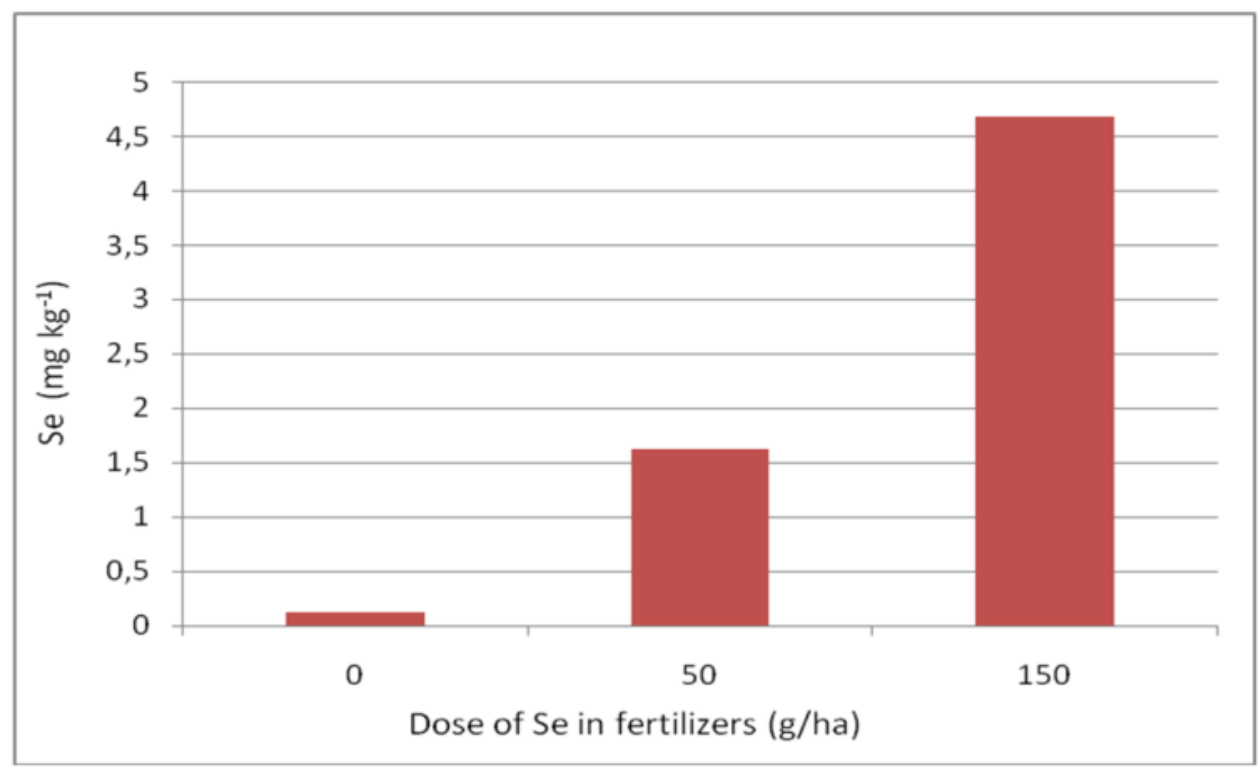

Figure 9. Selenium content $\left(\mathrm{mg} \mathrm{kg}^{-1}\right)$ in sunflower achenes [73]

Organ, in which significant amount of selenium received by a plant accumulates is determined with specific metabolism of each crop. At fortification of agricultural crops with selenium it is important that amount of selenium accumulated in edible or further processed parts of final products should increase the intake of selenium from food adequately and, in the case of regular consumption of product affect positively human health.

Other important factor at agronomic fortification with selenium is selection of chemical form of selenium, strategy of treatment and suitability of grown plant species for fortification. In Finland the above mentioned method of area application of sodium selenate $\left(\mathrm{Na}_{2} \mathrm{SeO}_{4}\right)$ has been selected based on soil conditions (low $\mathrm{pH}$ and redox potential) and complex attitude to biofortification of agricultural production; in acidic $\mathrm{pH}$ and reducing conditions sodium selenate is form of selenium being ready for plants. Second possible way of fortification with selenium is its application especially focused on particular crop in order to produce for market of extraordinary product with higher added value. Germ et al. [74] and Turakainen et al. [69] state that after foliar application selenium was effectively transported from leaves to potato tubers. Based on literature, suitable form of selenium for aimed foliar application can be sodium selenite $\left(\mathrm{Na}_{2} \mathrm{SeO}_{3}\right)$. At foliar application of selenium in the form of $\mathrm{Na}_{2} \mathrm{SeO}_{3}$

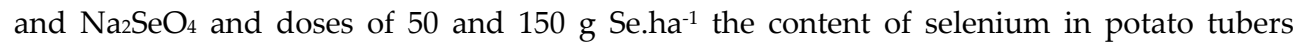
increased linearly for both forms of selenium. In comparison with $\mathrm{Na}_{2} \mathrm{SeO}_{3}$ sodium selenate was more efficient for higher applied doses. The experiment used the method of divided block in field conditions [11]. Demonstrative increase of selenium content in potato tubers where selenium was applied in form of $\mathrm{Na}_{2} \mathrm{SeO}_{3}$ foliary using field trial method, is described also by Munshi and Mondy [75]. This experiment included also the comparison of efficiency 
of selenium accumulation in the case of soil and foliar application of $\mathrm{Na}_{2} \mathrm{SeO}_{3}$. Soil application was more effective than foliar application. In the case of foliar application it is necessary to bear in mind that its efficiency depends on optimum climatic conditions before, as well as after treatment; their duration is based on rate of ion absorption by a plant. Linear increase of selenium content in plants after application of $\mathrm{Na}_{2} \mathrm{SeO}_{3}$ into soil is described by other authors, for example Kabata-Pendias and Pendias [27]; Koutník, Dočekalová [68]. Availability of applied selenium varies between 5 - $30 \%$ [30, 76].

Another positive characteristic being significant for selection of $\mathrm{Na}_{2} \mathrm{SeO}_{3}$ for fortification with selenium, is lower mobility of reduced forms of selenium in soil, increasing the safety of application of selenium for environment, especially for water sources [25] enabling application of higher doses of selenium. With development of oxidation conditions in a soil $\mathrm{SeO}_{3}{ }^{2-}$ is oxidized to the form being more available plants - $\mathrm{SeO}_{4}{ }^{2-}[31,27]$, becoming gradually available for plants. It was found out that $\mathrm{SeO}_{3}{ }^{2-}$ and less soluble forms of $\mathrm{SeO}_{4}{ }^{2-}$ (for example $\mathrm{BaSeO}_{4}$ ) work in a soil longer [77]. After application of $\mathrm{Na}_{2} \mathrm{SeO}_{3}$ the effect of fertilization in second year was $25 \%$ and in third year it was $15 \%$ in comparison with freshly applied dose [35].

At fortification with $\mathrm{SeO}_{4}{ }^{2-}$ bigger amount of selenium is accumulated in plants than asing $\mathrm{SeO}_{3}{ }^{2-}$. Results of the research showed that at using $\mathrm{SeO}_{4}{ }^{2-}$ the demonstrative part of total selenium is not metabolized and is deposed in inorganic form. According to Li et al. [43] $\mathrm{SeO}_{4}{ }^{2-}$ in xyleme is very mobile but little assimilated to organic forms. Kápolna et al. [78] state that at using $\mathrm{SeO}_{3}{ }^{2-}$ more organic compounds containing selenium have been formed in chives (Allium schoenoprasum L.) plants. Big amounts of Se-methylselenocysteine and selenocystine were detected. The plants treated with $\mathrm{SeO}_{3}{ }^{2-}$ accumulate selenium in organic forms, mostly in form of Se-met, while the plants treated with $\mathrm{SeO}_{4}{ }^{2-}$ accumulate selenium in form $\mathrm{SeO}_{4}{ }^{2-}[79]$.

Based on literature $\mathrm{Na}_{2} \mathrm{SeO}_{3}$ can be suitable form of selenium for increasing of content of selenium being available for body in agricultural crops at soil, as well as foliar application. Decisive criteria affecting the selection of selenium form for fortification is efficiency of selenium forms at soil and foliar application in current soil and climatic conditions. Soil application of $\mathrm{SeO}_{4}{ }^{2-}$ is suitable in wider extent in variable soil conditions with decisive factors $\mathrm{pH}$ and redox potential. Depending on plant species, selenate is partly metabolized to organic forms, part of it remains in inorganic forms being less available for human body. Disadvantage of $\mathrm{SeO}_{4}{ }^{2-}$ is its low availability in the market. There are only few producers of $\mathrm{SeO}_{4}{ }^{2-}$ in the world [80]. Effective using of applied selenium is determined also with chosen dose of selenium. Next research should be focused on suitable form and dose of selenium applied to plants [31], selection of optimum period for selenium application depending on development stages of plants, behaviour of various selenium forms in relation with uptake of selenium on various soil kinds and types, knowing their agrochemical characteristics [81]. Anyway, agricultural products fortified with selenium are appropriate natural source of selenium in human nutrition. 


\section{Author details}

P. Ježek, P. Škarpa, T. Lošák and J. Hlušek

Department of Agrochemistry, Soil Science, Microbiology and Plant Nutrition, Faculty of Agronomy, Mendel University in Brno, Brno, Czech Republic

M. Jůzl and P. Elzner

Department of Crop Science, Breeding and Plant Medicine, Faculty of Agronomy,

Mendel University in Brno, Czech Republic

\section{Acknowledgement}

This study was supported by the National Agency for Agriculture Research of the Czech Republic No. QH 81271 called "Optimization of the nutrition and fertilization of the sunflower with the aim to increase the yield and quality of production" and by the Research plan No. MSM6215648905 "Biological and technological aspects of sustainability of controlled ecosystems and their adaptability to climate change", which is financed by the Ministry of Education, Youth and Sports of the Czech Republic and Research project NAZV No. QI101A184 called „Potato Growing Technology - New Friendly Approaches to the Environment".

\section{References}

[1] Mach, I. Selenium-nutritive deficiency and efficacy in supplements. Vitamins 2008, nutrition and diagnostics. The abstract book. Univerzita Tomáše Bati ve Zlíně. 2008, p. 61.

[2] Rayman, M. P. The importance of selenium to human health. The lancet. 2000, Vol. 356, Issue 9225, p. 233-241.

[3] Surai, P. F. Selenium in nutrition and health. Nottingham university press, 2006. 974 p.

[4] Kvíčala, J. Zvýšení příjmu mikronutrientu selenu-utopie, fikce, prozřetelnost či nutnost?II. část. Interní medicína pro praxi. 2003b, Issue 7 , p. 354-359.

[5] Pedrero, Z., Madrid, Y. Novel approaches for selenium speciation in foodstuffs and biological specimens: A review. Analytica chimica acta. 2009, Vol. 634, Issue 2 , p. 135-152.

[6] Rayman, P. R. Food-chain selenium and human health: emphasis on intake. British journal of nutrition. 2008, Vol. 100, Issue 2, p. 254-268.

[7] Daniels, L. A. Selenium metabolism and bioavailability. Biological trace element research. 1996, Vol. 54, Issue 3, p. 185-199.

[8] Combs, G. F., JR. Selenium in global food systems. British journal of nutrition. 2001, Vol. 85, Issue 5, p. 517-547.

[9] Pyrzynska, K. Selenium speciation in enriched vegetables. Food chemistry. 2008, Vol. 114, Issue 4, p. 1183-1191.

[10] Pedrero, Z., Madrid, Y., Cámara, C. Selenium species bioaccessibility in enriched radish (Raphanus sativus): A potential dietary source of selenium. Journal of agricultural and food chemistry. 2006, Vol. 54, Issue 6, p. 2412-2417. 
[11] Poggi, V., Arcioni, A., Fillipiny, P., Piffery, P. G. Foliar application of selenite and selenate to potato (Solanum tuberosum): Effect of a ligand agent on selenium content of tubers. Journal of agricultural and food chemistry. 2000, Vol. 48, Issue 10, p. 4749-4751.

[12] Velíšek, J. Chemie potravin 2.díl. Tábor: Ossis, 1999. 304 s.

[13] Finley, J. W. Increased intakes of selenium-enriched foods may benefit human health. Journal of the science of food and agricultures. 2007, Vol. 87, Issue 9, p. 1620-1629.

[14] Rayman, M. P., Infante, H. G., Sargent, M. Food-chain selenium and human health: spotlight on speciation. British journal of nutrition. 2008, Vol. 100, Issue 2, p. 238-253.

[15] Finley, J. W. Bioavailability of selenium from foods. Nutrition reviews. 2006, Vol. 64, Issue 3, p. 146-151.

[16] Brown, K. M., Arthur, J. R. Selenium, selenoproteins and human health: a review. Public health nutrition. 2001, Vol. 4, Issue 2B, p. 593-599.

[17] Böck, A., Forchhammer, K., Heider, J., Leinfelder, W., Sawers, G., Veprek, B., Zinoni, F. Selenocysteine-the 21st amino-acid. Molecular microbiology. 1991, Vol. 5, Issue 3, p. 515520.

[18] Tapiero, H., Townsed, D. M., Tew, K. D. The antioxidant role of selenium and selenocompounds. Biomedicine E pharmacotherapy. 2003, Vol. 57, Issue 3-4, p. 134-144.

[19] Kvíčala, J. Zvýšení př́jmu mikronutrientu selenu-utopie, fikce, prozřetelnost či nutnost?-I. část. Interní medicína pro praxi. 2003a, Issue 6 , p. 295-300.

[20] Food and Nutrition Board, Institute of Medicine (U. S.). Dietary reference intakes for vitamin C, vitamin E, selenium and carotenoids. National academies press, 2000. $506 \mathrm{p}$.

[21] Navarro-Alarcón, M., López-Martínez, M. C. Essentiality of selenium in the human body: relationship with different diseases. The science of the total environment. 2000, Vol. 249, Issue 1-3, p. 347-371.

[22] Dhillon, K. S., Dhillon, S. K. Distribution and management of seleniferous soils. Advances in agronomy. Academic press, San Diego, USA. 2003, Vol. 79, p. 119-184.

[23] Oldfield, J. E. Selenium in maps. The bulletin of selenium-tellurium development association. April, 1995.

[24] Gupta, U. C., Gupta, S. C. Selenium in soils and crops, its deficiencies in livestock and humans: implications for management. Communications in soil science and plant analysis. 2000, Vol. 31, Issue 11-14, p. 1791-1807.

[25] Oldfield, J. E. Selenium supplementation via fertilizer amendment. The bulletin of selenium-tellurium development association. Special issue, 1998.

[26] Tan, J., Zhu, W., Wang, W., Li, R., Hou, S., Wang, D., Yang, L. Selenium in soil and endemic diseases in China. The science of total environment. 2002, Vol. 284, Issue 1-3, p. 227-235.

[27] Kabata-Pendias, A., Pendias, H. Trace elements in soils and plants. $3^{\text {rd }}$ edition. Boca Raton, London, New York, Washington, D.C.: CRC Press, 2001. 413 p.

[28] Haygarth, P. M., Harrison, A. F., Jones, K. C. Geographical and seasonal variation in deposition of selenium to vegetation. Environmental science and technology. 1993, Vol. 27, Issue 13, p. 2878-2884.

[29] Aspila, P. History of selenium supplemented fertilization in Finland. Proceedings Twenty years of selenium fertilization. MTT Agrifood research Finland, 2005, p. 8-13. 
[30] Eich-Greatorex, A., Sogn, T. A., Øgaard, A. F., Aasen, I. Plant availability of inorganic and organic selenium fertilizer as influenced by soil organic matter content and $\mathrm{pH}$. Nutrient cycling in agroecosystem. 2007, Vol. 79, Issue 3, p. 221-231.

[31] Kopsell, D. A., Kopsell, D. E. Selenium. In BARKER, A. W., PILBEAM, D. J. Handbook of plant nutrition. CRC Press. 2007, p. 515-549.

[32] Alemi, M. H., Goldhamer, D. A., Nielsen, D. R. Modeling selenium transport in steadystate, unsaturated soil columns. Journal of environmental quality. 1991, Vol. 20, Issue 1, p. 89-95.

[33] Hartikainen, H. Biogeochemistry of selenium and its impact on food chain quality and human health. Journal of trace elements in medicine and biology. 2005, Vol. 18, Issue 4, p. 309-318.

[34] Sager, M. Selenium in agriculture, food and nutrition. Pure and applied chemistry. 2006, Vol. 78, Issue 1, p. 111-133.

[35] Gissel-Nielsen, G. Effects of selenium supplementation of field crops. In Frankenberger, W. T., ENGBERG, R. A. et al. environmental chemistry of selenium. Marcel Dekker, Inc., 1998. p. 99-112.

[36] Zayed, A., Lytle, C. M., Terry, N. Accumulation and volatilization of different chemical species of selenium by plants. Planta. 1998, Vol. 206, Issue 2, p. 284-292

[37] Benuelos, G. S., Meek, D. W. Selenium accumulation in selected vegetables. Journal of plant nutrition. 1989, Vol. 12, Issue 10, p. 1255-1272.

[38] Nátr, L. Fotosyntetická produkce a výživa lidstva. ISV nakladatelství, 2002. $423 \mathrm{s.}$

[39] Terry, N., Zayed, A. M., De Souza, M. P., Tarun, A. S. Selenium in higher plants. Annual review of plant physiology and plant molecular biology. 2000, Vol. 51, p. 401-432.

[40] Sors, T. G., Ellis, D. R., Salt, D. E. Selenium uptake, translocation, assimilation and metabolic fate in plants. Photosynthesis research. 2005, Vol. 86, Issue 3, p. 373-389.

[41] Arvy, M. P. Selenate and selenite uptake and translocation in bean-plants (Phaseolus vulgaris). Journal of experimental botany. 1993, Vol. 44, Issue 263, p. 1083-1087.

[42] Asher, C. J., Butler, G. W., Peterson, P. J. Selenium transport in root systems of tomato. Journal of experimantal botany. 1997, Vol. 28, Issue 103, p. 279- 291.

[43] Li, H. F., Mcgrath, S. P., Zhao, F. J. Selenium uptake, translocation a speciation in wheat supplied with selenate or selenite. New phytologist. 2008, Vol. 178, Issue 1, p. 92-102.

[44] Johnsson, L. Selenium uptake by plants as a function of soil type, organicmatter content and pH. Plant and soil. 1991, Vol. 133, Issue 1, p. 57-64.

[45] Haygarth, P. M., Harrison, A. F., Jones, K. C. Plant selenium from soil and the atmosphere. Journal of environmental quality. 1995, Vol. 24, Issue 4, p.768-771.

[46] Mincher, B. J., Mionczynski, J., Hnilicka, P. A. Soil redox chemismy limitation of selenium concentration in Carex species sedges. Soil science. 2007, Vol. 172, Issue 9, p. 733-739.

[47] Goh, K.-H., Lim, T.-T. Geochemistry of inorganic arsenic and selenium in a tropical soil: effect of reaction time, $\mathrm{pH}$, and competitive anions on arsenic and selenium adsorption. Chemosphere. 2004, Vol. 55, Issue 6, p. 849-859. 
[48] Nakamaru, Y. M., Sekine, K. Sorption behavior of selenium and antimony in soils as a function of phosphate ion concentration. Soil science and plant nutrition. 2008, Vol. 54, Issue 3, p. 332-341.

[49] Cartes, P., Shene, C., Mora, M. De La Luz. Selenium distribution in ryegrass and its antioxidant role as affected by sulfur fertilization. Plant and soil.2006, Vol. 285, Issue 1-2, p. 187-195.

[50] Bukovac, M. J., Wittwer, S. H. Absorption and mobility of foliar applied nutrients. Plant physiology. 1957, Vol. 32, Issue 5, p. 428-435.

[51] Wójcik, P. Uptake of mineral nutrients from foliar fertilization (review). Journal of fruit and ornamental plant research. 2004, Vol. 12, Special edition, p. 201-218.

[52] Marschner, H. Mineral nutrition of higher plants. 2nd edition. Elsevier science \& technology books, $1995.889 \mathrm{p}$.

[53] Xue, T., Hartikainen, H., Piironen, V. Antioxidative and growthpromoting effect of selenium on senescing lettuce. Plant and soil. 2001, Vol. 237, Issue 1, p. 55-61.

[54] Pedrero, Z., Madrid, Y., Hartikainen, H., Cámara, C. Protective effect of selenium in Broccoli (Brassica oleracea) plants subjected to cadmium exposure. Journal of agricultural and food chemistry. 2008, Vol. 56, Issue 1, p. 266-271.

[55] Rani, N., Dhillon, K. S., Dhillon, S. K. Critical levels of selenium in different crops grown in an alkaline silty loam soil treated with selenite-Se. Plant and soil. 2005, Vol. 277, Issue 1-2, p. 367-374.

[56] Dhillon, K. S., Dhillon, S. K. Selenium toxicity in soils, plants and animals in some parts of Punjab, India. International journal of environmental studies. 1991, Vol. 37, Issue 1-2, p. 15-24.

[57] Whitehead, D. C. Nutrient elements in grassland: Soil-plant-animal relationship. CABI publishing, 2000. $369 \mathrm{p}$.

[58] Whanger, P. D. Selenocompounds in plants and animals and their biological significance. Journal of the American collage of nutrition. 2002, Vol. 21, Issue 3, p. 223-232.

[59] Arnault, I., Auger, J. Seleno-compounds in garlic and onion. Journal of chromatography. 2006, Vol. 1112, Issue 1-2, p. 23-30.

[60] Zhang, L., Shi, W., Wang, X. Difference in selenite absorption between highand lowselenium rice cultivars and its mechanism. Plant and soil. 2006, Vol. 282, Issue 1-2, p. 183-193.

[61] Meija, J., Montes-Bayón, M., Le Duc, D. L. Terry, N., Caruso, J. A. Simultaneous monitoring of volatile selenium and sulfur species from Se accumulating plants (wild type and genetically modified) by GC/MS and GC/ICPMS using solid-phase microextraction for sample introduction. Analytical chemistry. 2002, Vol. 74, Issue 22, p. 5837-5844.

[62] Ježek, P., Hlušek, J., Lošák, T., Jůzl, M., Elzner, P., Kráčmar, S., Buňka, F., Martensson, A. Effect of foliar application of selenium on the content of selected amino acids in potato tubers (Solanum tuberosum L.). Plant, soil and environment. 2011. Vol. 57, Issue 7, p. 315-320. 
[63] Aro, A., Alfthan, G., Ekholm, P., Varo, P. Effects of selenium supplemantation of fertilizers on human nutrition and selenium status. In Frankenberger, W. T., ENGBERG, R. A. et al. environmental chemistry of selenium. Marcel Dekker, Inc., 1998. p. 81-97.

[64] Hartikainen, H. Antioxidative and growth-promoting effect of selenium on plants. The bulletin of selenium-tellurium development association. April, 2002.

[65] Ekholm, P., Eurola, M., Venäläinen, E.-R. Selenium content of foods and diets in Finland. Proceedings Twenty years of selenium fertilization. MTT Agrifood research Finland, 2005, p. 39-45.

[66] Eurola, M., Ekholm, P., Venäläinen, E-J. Selenium supplemented fertilization-effect on the selenium content of foods and the selenium intake in Finland. Nordic association of agricultural scientists seminar no 370. Essential trace elements for plants, animals and humans. Agricultural university of Iceland. 2005, p. 49-51.

[67] Carvalho, K. M., Gallardo-Williams, M. T., Benson, R. F., Martin, D. F. Effects of selenium supplementation of four agricultural crops. Journal of agricultural and food chemistry. 2003, Vol. 51, Issue 3, p. 704-709.

[68] Koutník, V., Dočekalová, H. Distribuce selenu v rostlinách ovsa setého během ontogeneze. Rostlinná výroba. 1994, Vol. 40, Issue 2, p. 163-172.

[69] Turakainen, M., Hartkainen, H., Seppänen, M. M. Effect of selenium treatments on potato (Solanum tuberosum) growth and concentration of soluble sugars and starch. Journal of agricultural and food chemistry. 2004, Vol. 52, Issue 17, p. 5378-5382.

[70] Jůzl, M., Hlušek, J., Elzner, P., Lošák, T., Zemková, L'. The effect of selenium applications on yields and quality of potatoes. Proceedings of international conference Plant nutrition and its prospects, MZLU v Brně, 2007, p. 275-278.

[71] Škarpa, P., Richter, R. Foliar Nutrition of Poppy Plants (Papaver Somniferum L.) with Selenium and the Effect on its Content in Seeds. Journal of Elementology. 2011. sv. 16, č. 1, 85-92.

[72] Schneiter, A. A., Miller. J. F. Description of Sunflower Growth Stages. Crop Science 1981, Vol. 21, p. 901-903.

[73] Škarpa, P. 2011 Periodická zpráva projektu QH 81271 called "Optimization of the nutrition and fertilization of the sunflower with the aim to increase the yield and quality of production" / 2011.

[74] Germ, M., Kreft, I., Stibilj, V., Urbanc-Berčič, O. Combined effect of selenium and drought on photosynthesis and mitochondrial respiration in potato. Plant physiology. 2007, Vol. 45, Issue 2, p. 162-167.

[75] Munshi, C. B., Mondy, N. I. Glycoalkaloid and nitrate content of potatoes as affected by method of selenium application. Biological trace element research. 1992, Vol. 33, p. 121-127.

[76] Yli-Halla, M. Influence of selenium fertilization on soil selenium status. Proceedings Twenty years of selenium fertilization. MTT Agrifood research Finland, 2005, p. 25-32.

[77] Broadley, M. R., White, P. J., Bryson, R. J., Meacham, M. C. et al. Biofortification of UK food crops with selenium. Proceedings of the nutrition society. 2006, Vol. 65, Issue 2, p. 169-181. 
[78] Kápolna, E., Shah, M., Caruso, J. A., Fodor, P. Selenium speciation studies in Seenriched chives (Allium schoenoprasum) by HPLC-ICP-MS. Food chemistry. 2007, Vol. 101, Issue 4, p. 1398-1406.

[79] De Souza, M. P., Pilon-Smits, E. A., Lytle, C. M. Hwang, S., Tai, J., Honma, T. S., Yeh, L., Terry, N. Rate-limiting steps in selenium assimilation and volatilization by Indian mustard. Plant physiology. 1998, Vol. 117, Issue 4, p. 1487-1494.

[80] Hero, H. Technical solution adding selenium to fertilizers. Proceedings Twenty years of selenium fertilization. MTT Agrifood research Finland, 2005, p. 16-17.

[81] Ducsay, L., Ložek, O., Varga, L., Marček, M. Zvyšovanie obsahu selénu v obilninách. Agrochémia. 2008, Vol. 12, Issue 2, s. 3-6. 